

\title{
The Characteristics of the Leaders on Effective Commitment
}

\author{
Farah Wahida Binti Jaafar and Puspa Liza Binti Ghazali
}

To Link this Article: http://dx.doi.org/10.6007/IJARBSS/v8-i12/5072

DOI: $10.6007 /$ IJARBSS/v8-i12/5072

Received: 19 Nov 2018, Revised: 24 Dec 2018, Accepted: 27 Dec 2018

Published Online: 29 Dec 2018

In-Text Citation: (Jaafar \& Ghazali, 2018)

To Cite this Article: Jaafar, F. W. B., \& Ghazali, P. L. B. (2018). The Characteristics of the Leaders on Effective Commitment. International Journal of Academic Research in Business and Social Sciences, 8(12), 777-784.

Copyright: (C) 2018 The Author(s)

Published by Human Resource Management Academic Research Society (www.hrmars.com)

This article is published under the Creative Commons Attribution (CC BY 4.0) license. Anyone may reproduce, distribute, translate and create derivative works of this article (for both commercial and non-commercial purposes), subject to full attribution to the original publication and authors. The full terms of this license may be seen at: http://creativecommons.org/licences/by/4.0/legalcode

Vol. 8, No. 12, 2018, Pg. 777 - 784

http://hrmars.com/index.php/pages/detail/IJARBSS

JOURNAL HOMEPAGE

Full Terms \& Conditions of access and use can be found at http://hrmars.com/index.php/pages/detail/publication-ethics 


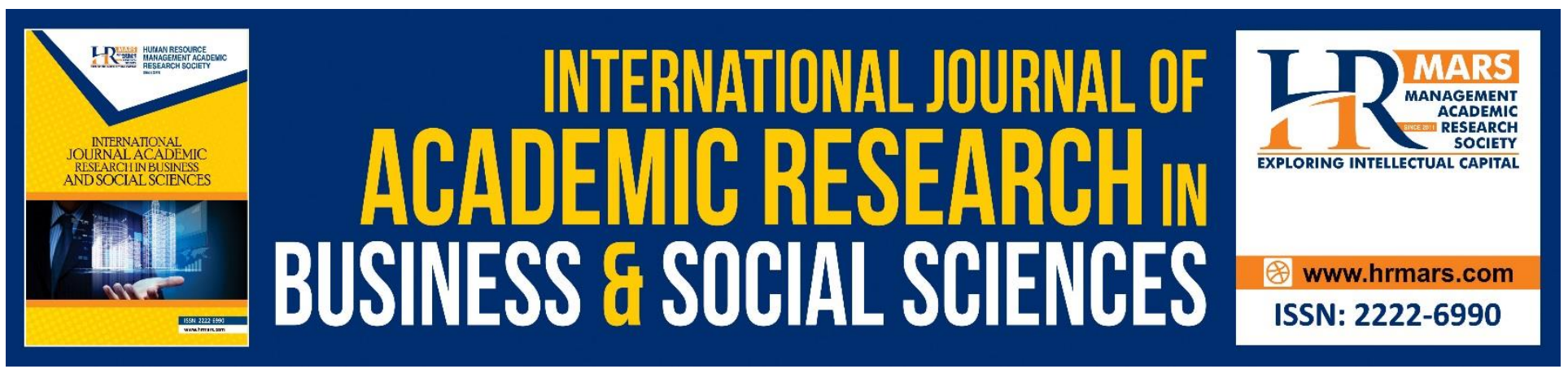

\title{
The Characteristics of the Leaders on Effective Commitment
}

\author{
${ }^{1}$ Farah Wahida Binti Jaafar and ${ }^{*}$ Puspa Liza Binti Ghazali \\ $1 \& 2^{*}$ Faculty of Economic and Management Science, Universiti Sultan Zainal Abidin, 21300 Kuala \\ Nerus, Terengganu. Malaysia
}

\begin{abstract}
School principals have a significant influence on teacher's commitment. Through the literature review, this paper aims to identify the relationship between leadership styles, emotional intelligent and decision making among principals on teachers' commitment and generate some hypotheses regarding this issue. Teacher's commitment is factors that contribute to the school effectiveness as well as to the quality of school education. From the literature review that has been done, there are three important variables act as the antecedents that influence the level of teacher's commitment. The antecedents are principals' leadership style, principals' emotional intelligent and principals' decision making. So that, this paper tries to examine the relationship and the important between leadership styles, emotional intelligent and decision-making among the principals and how it will affect teacher's commitment. The study provides useful information about principal leadership and how it could contribute to increase the level of teachers' commitment. In order to increase the commitment among teachers, principals should use different kind of leadership styles, know how to handle with their own emotional intelligent and react with the reasonable decision-making that respond better with the different situations.
\end{abstract}

\section{INTRODUCTION}

An education is the key role for the economic development. Ministry of Education has plan the great changes in order to change Malaysia into an establish country. It seems that to determine the success in educational context, the Ministry need to focus and upgrade our educational system. So that, Education Development Master Plan (PIPP 2006-2010) and Malaysian Education Blueprint (PPPM 2013-2025) has been created to maintain the quality of education in Malaysia. In globalization era of educational system needs to create the healthy competitive surroundings. The members of school are consisting the teachers and students that leading by the principals. Teachers need a leader who can influence and stimulate them to be more efficient in teaching while students will depend heavily on teachers to obtain good outcomes and skills in learning. The effectiveness of the school is highly depending upon on the leadership of the principal (Rowena, 2014). Their attitudes are definite to the 
positive outcomes from the program. The important roles in the performance or the victory of a school are the principals who used to be as the leaders. Leaderships are the leaders handling their own powers and choosing the rational leadership style. The ability to control the emotions and their instructional leader skills among the principals acknowledge them to influence teachers in achieving effective teaching outcomes. The principal's ability to control their emotional intelligence and choosing the right leadership style is crucial in determine the school success. Teacher's professional commitment has a significant relationship on educational reform. In school context, it seems that in achieving the school success focused on to increase the student learning outcomes, teacher's professional commitment is really important. There are a lot of evidences for the professional development and high quality designed for effective principles. The important parts in the development of professional learning cultures in schools are develop the guidelines for the design, delivery and evaluation of outcomes. As we all known, develop lists of design principles is important. But, rather than implementing them effectively the identifying process is generally much easier. In the school environments, the hard work comes in putting the design principles into practice with real people. In school, the principals react in showing the impact on the teacher's professional development and quality. They influence the implementation of the principles. The principals are responsible in order to create the good environment for the school organization to maintain positive, sustain the enjoyable teaching situation as well as for the students learning environments. The aim of this article is to examine the characteristic of the principals in order to influence teacher's commitment and the school development. What are the predictors for the good principals? What are the antecedents of the principals that influence teacher's professional commitment? The analysis on school principal's roles and responsibilities in teacher commitment, the impact of the characteristic in principals to the growth of commitment among teachers, environment to achieve the school goals toward success will be analyzed in this conceptual article.

\section{LITERATURE REVIEW}

This paper aims to discuss the significant relationship of the three variables on principal's leadership on teacher's commitment. The variables are leadership styles, emotional intelligent and decision making. Through the teachers' perceptions, this paper will analyze on how all these variables effect positively onto teachers' commitment and also to school success as well as to the student outcomes.

\section{Leadership Style}

Nowadays, the quality leaders are needed not only in public organization but also in private sectors. The leadership stress the subject character (Yukl, 1992). In Hoy and Miskel (2008) state that leadership is the affecting action to the committee of the organization in every aspects of activities. It seems that leadership process seems to have the relationship with the process of influencing. In Bush, Bell and Middlewood (2010), they disagree with the concept of leadership process that assumes the intentional influence is central. For Iszatt-White and Sounders (2014), they define leadership as an attempt to influence others, by practicing power, actions and behaviours of others. Nowadays, in educational scenario from administration to management and more recently to leadership has been a remarkable shift. There's an evidence that school leadership is considered to be the main element in effective schools even though we can't simply make assumption because of 
the lack of relevant discussion into this matter. It seems that it has a mainly indirect impact on student learning and school effectiveness. According to Kumari (2017) the participative leadership style is the most dominant style that has been practiced by the principals and the women principals tend to use it frequently rather than the male principals. From the findings, it shown that the principals with high and low of emotional intelligent also preferred the participative style as well as the principals with high and low organizational role stress. The weaknesses from this jurnal are the author only focus on participative leadership style only without considered any other leadership styles. It only focus on how the emotional intelligent affecting the participative leadership. Saleem, Batool and Khattak (2017) define in his journal that most of the employed teachers in private sector are 60 years and above. So that, with that kind of situation, the sector will lack of ineffective teaching and learning because of the poor stamina. The quality of private educational sector is good compared to public sector. But, the private teachers are not fully committed in their job because of no job security. The private principals mostly practice an autocratic style. As the recommendations, they should share their visions and value with their teachers to create healthy working environment. The principals with high emotional intelligent has a significant relationship towards teachers' commitment and the principals' leadership style has a correlation with emotional intelligent. But, the result only based on autocratic leadership style only. There was a positive significant relationship between principals' transformational leadership style and teachers' commitment. All four dimensions in transformational leadership show higher correlation with teachers' commitment. There's no difference in principals' leadership practice based on principals' level of education (Raman, Mey, Don, Daud, \& Khalid, 2015). But the lack of this result is it only focus on transformational leadership style only without consider the other leadership style.

\section{Emotional Intelligent}

Schools being led effectively necessary on school principal emotional intelligent. It is due to the changes taking place in education system lately. According to (Abdul, 2007; Goleman, 2001; Nurul et al., 2013), the effective leader needs high emotional intelligent and in the context of social leadership, there's exist the leadership practices. According to Goleman (2001), the ability to recognize own feelings and others feeling, ability to motivate and handle the emotions of his own and others known as emotional intelligent. The emotional intelligent can be divided into the social aspects, education and leadership. The success whether at home, school or in a workplace lead by the emotional intelligent (Goleman et. all 2002). In Goleman (2000, 2001), he defines that an individual's success in life is mostly dependent on the emotional quotient (EQ) rather than the intelligence quotient (IQ). According to Syarif (2014), the important of emotional intelligent has been shown by the previous researchers on their studies that the leaders' leadership effectiveness influence from their own emotional intelligent. High level of emotional intelligent among the leaders has a significant on the effective leadership behavior. They able to influence the members of the organization to succeed. In business sector, the high level of emotional intelligent among the leaders can improve their performance. Emotional intelligence is crucial in the business context but less study conducted to investigate the relationship between instructional leadership and emotional intelligence (Singh, 2006; Singh and Dali, 2013). Although the researchers (Beatty, 
2007; Dinham, 2005; Zepeda, 2006) has identified the influential of emotional intelligence to produce effective instructional leaders, but less known the impact and effect of emotional intelligence on instructional leadership of principals. According to Abdul (2007) and Yulk (2013), the individual who shows a good level of emotional intelligence can drive the organization successfully. According to (Asrar-ul-Haq et al., 2017), emotional intelligent has significant impact on teacher's job performance as well as to the teachers' commitment. Emotional intelligent is the significant tool that adjusts their emotions and societal challenges. Trait based on emotional intelligent has the positive influence on performance so that the teachers with good emotional intelligent lead to improve performance. High emotional intelligent will maintaining the positive psychological condition. Limited research proves that emotional intelligent is related to positive work-related outcomes particularly in the education sector. So that, we can say that the principals with high level of emotional intelligent tend to lead their organizations There's no discussion on how emotional intelligent on itself can possibly create such a good leaders without the reasonable and rational leadership styles. Hur, Berg and Wilderom (2011) said that motivation related with the emotional intelligent. Emotional intelligent will contribute the effective leaders. Emotional intelligent inherently associated with transformational leadership. Previous researchers found that emotional intelligent has a connection with transformational leadership. Emotional intelligent team leaders are classified as more effective by their teams, more effective in forming excellent service climate, when practice transformational leadership behaviour. Competent leaders should practice the transformational leadership and feel necessity the good emotional intelligent. High emotional intelligent brings up the high potential to become transformational leadership leaders. This journal only focuses on the findings of transformational leadership. According to Badea (2010), leaders with high empathy level able to read others feeling/nonverbal. They also able to know their actions, intuits their thoughts and feeling. Leaders with high emotional intelligent can detect sign of anxiety. The emphatic ability is so important in leadership. Recognize the emotional uncertainties, can increase satisfaction and performance among subordinates and organization.

\section{Decision Making}

Decision making is the series of action in choosing something crucial. It happened in a small team or in an organization. According to Kreitner (2008), he defines that decision making is the action of selecting. Decision-making is an important factor in any organization (Hengpiya, 2008). Scott and Bruce (1995) define decision-making style as the respond design used by an individual who anticipate a situation that rely upon on decision. Cultural background impacts leadership characteristics and behaviours. Leaders are still the main element in making collaboration in choosing the good decision. Culture can force relevant and irrelevant result. Communication is a basic nature of leadership. Multi cultural diversity lead to conflict between members but the other side, offer a chance to exchange knowledge and support each other. According to Jalal (2017), good communication between leaders and followers improve leaders' decision making and focus on the important of decision making in organization. Exists the correlation between decision making style and leadership style of school principals (Al-Omari, 2013). Directive decision making style was predominant in school principals. 
Constituency centered administration was predominant in school principals. Decision making depends on internal factors and organizations contexts. Decision making influences by the individual's responsibility. The process of decision making based on the available information. Decision making faced at least two alternatives. Decision making are predict stress, motivation, principals' school abilities and general manner of thinking. Refer to the age context, it seems that there's no correlation on the rational decision and the tendency of procrastination. It has a correlation with rationality, intuitive, dependent, avoidant and spontaneous decision-making styles. Attitudes and behaviors towards decision is the important role in determining the characteristics of the task. The different decision-making styles can accomplish the different administrational conditions and shows their own behavioral pattern (procrastination behavior). The decision steps in school based on the degree of the problems matter. The different decision-making styles adjudge the level of the decision-making behavior. Decision making is influenced by the inner characteristics of the organization members. Ugurlu (2013) said that the different personality traits will generate different of decision making styles.

\section{DISCUSSION}

From the literature review, we can conclude that the good principals need to stress on a good leadership style with higher emotional intelligent and can make the rational decisions in order to get the good commitments in the organizations. In business context, employer's behavior also seems to be crucial especially in subordinate commitment. The employer's leadership and the way how they handle the critical situations in organization reflect the employee's productivity. Previous research states that transformational leadership style is the dominant style that contributes to the influences on employee's commitment. The employer having transformational leadership styles tend to increase their subordinate commitment. Transformational leadership reacts as a predictor to the subordinate commitment (Shrestha, 2015). In economic and management context, businesses need skilled, competent and committed employees as an effective team member to succeed. Failure to ensure this by managers or supervisors can lead to the loss of valued employees who place a premium on the success of organization. Positive influences are essential to strengthening employee commitment. Leadership is one of the most critical issues and one of the least assumed concepts in the corporate world. Leadership is fundamental for productive organization and social working. The very nature of leadership is its consequence steps and its derivable result. This process is determined by the leaders and follower's characteristic. The workplace is changing dramatically and demands for the highest quality of product and service is increasing. To remain competitive in the face of these pressures, employee commitment is crucial. Employee commitment can result in benefits such as leadership effectiveness. The commitment of employees to the organization is a factor for sustainable and effective growth to the organization as well as to the economic growth. So that, if the level of commitment among the subordinates is high, the profit, quality, productivity and the performance of the organization will also increase. 
INTERNATIONAL JOURNAL OF ACADEMIC RESEARCH IN BUSINESS AND SOCIAL SCIENCES

Vol. 8, No. 12, Dec, 2018, E-ISSN: 2222-6990 @ 2018 HRMARS

\section{CONCLUSION}

The need for better employer leadership is important to keep remind this positive growth. Having effective leadership style for the organization to retain competent is crucial (Teshome, 2011). The capability of an organization to enhance human capital, largely rely on the leadership styles that boost the employee commitment. The quality of leadership had shown on the commitment of the subordinate (Awan and Mahmood, 2009; Ponnu and Tennakoon, 2009). Therefore, in the future, we need to develop a new model for the role of efficient leaders for the sake of the successful organization system.

\section{REFERENCES}

Abdul, G.A. (2007). Emotional intelligence and leadership effectiveness of school managers in Malaysia. Educationist, 1(2): 75-81

Al-Omari, A. A. (2013). The relationship between decision making styles and leadership styles among public schools principals. International Education Studies, 6(7), 100-110. https://doi.org/10.5539/ies.v6n7p100

Asrar-ul-Haq, M., Anwar, S., \& Hassan, M. (2017). Impact of emotional intelligence on teacher's performance in higher education institutions of Pakistan. Future Business Journal, 3(2), 87-97. https://doi.org/10.1016/j.fbj.2017.05.003

Badea, L. (2010). The Role of Empathy in Developing the Leader's Emotional Intelligence, XVII(2), 69-78.

Beatty, B. (2007). Going through the emotions: Leadership that gets to the heart of school renewal. Australian Journal of Education, 51(3): 328-340.

Bush, T., Bell, L., Middlewood D. (eds), (2010) The Principles of Educational Leadership \& Management, Sage, London

Dinham, S. (2005). Principal leadership for outstanding educational outcomes. Journal of Educational Administration, 43(4): 338-356

Ejimofor, F. O. (2007). Principals' Transformational Leadership Skills and Their Teachers' Job Satisfaction in Nigeria (Doctoral dissertation). Cleveland State University, USA.

Goleman, D. (2001). The emotionally intelligent workplace. Bantam Books, New York, USA.

Goleman, D., Boyatzis, R., and McKee, A. (2002). Primal leadership: Realizing the power of emotional intelligence. Harvard Business School Press, Boston, USA.

Hengpiya, A. (2008). Construct validation of a school principal decision-making styles scale. Malaysian Journal of Learning \& Instruction, 5, 41-61.

Hoy, W. K., \& Miskel, C. G. (2008). Educational administration: Theory, research, and practice. (8th Edition). New York: McGraw-Hill, Inc

Hur, Y., Berg, P. T. Van Den, \& Wilderom, C. P. M. (2011). Transformational leadership as a mediator between emotional intelligence and team outcomes is. The Leadership Quarterly, 22(4), 591603. https://doi.org/10.1016/j.leaqua.2011.05.002

Jalal, A. (2017). Impacts of Organizational Culture on Leadership's Decision- Making. Journal of Advances in Management Sciences \& Information Systems, 3, 1-8. Retrieved from http://www.lifescienceglobal.com/pms/index.php/jamsis/article/view/4383

Kumari, U. (2017). Leadership styles of principals in relation to organizational role stress, emotional 
INTERNATIONAL JOURNAL OF ACADEMIC RESEARCH IN BUSINESS AND SOCIAL SCIENCES

Vol. 8, No. 12, Dec, 2018, E-ISSN: 2222-6990 @ 2018 HRMARS

intelligence and gender. International Journal of Humanities and Social Science Research, 3(1), 2455-2070. Retrieved from www.socialresearchjournals.com

Kreitner, R. (2008). Management. (11th Edition). Canada: Houghton Mifflin Harcourt

Nurul, H.M.N., Maarof, R., Hanina, H., and Ibrani, A.A. (2013). Model fitness on emotional intelligence, personality traits and leadership behavior on job performances. Journal Teknologi, 61(1): 47-55.

Raman, A., Mey, C. H., Don, Y., Daud, Y., \& Khalid, R. (2015). Relationship between principals' transformational leadership style and secondary school teachers' commitment. Asian Social Science, 11(15), 221-228. https://doi.org/10.5539/ass.v11n15p221

Rowena, M. (2014). EQ, not just IQ: The relationship between emotional intelligence and the success of high school principals who have been awarded the Illinois Principals Association's high school principal of the year award. Ph.D. Dissertation, Loyola University Chicago, USA.

Saleem, Z., Batool, S., \& Khattak, S. R. (2017). Relationship between Leadership Styles and Organizational Commitment: Moderating Role of Emotional Intelligence and Organizational Support. Journal of Managerial Sciences, 2017 - Qurtuba.edu.pk, Volume xi, 71-84. Retrieved from qurtuba.edu.pk

Shrestha, A. (2015). Leadership styles, subordinates' satisfaction with the leader and perceived effectiveness: A study in a Nepali telecommunications company Kathmandu University School of Management Occasional Paper Leadership Styles, Subordinates' Satisfaction with th, (November).

Singh, D. (2006). Emotional intelligence at work: a professional guide. Response Book, New Delhi, India.

Singh, P. and Dali, C.M. (2013). Need for emotional intelligence to develop principals' social skills. African Education Review, 10(3): 502-519.

Scott, S. G., \& Bruce, R. A. (1995). Decision-making style: The development and assessment of a new measure. Educational and psychological measurement, 55(5), 818-831. Https://doi.org/10.1177/0013164495055005017

Teshome, T. (2011). Addis Ababa University College of Management, Information, and Economic Sciences School of Business and Public Administration MBA Program. Journal of Sustainable Development in Africa, 2(3)

Uğurlu, C. T. (2013). Effects of decision-making styles of school administrators on general procrastination behaviors. Eurasian Journal of Educational Research.

Vroom, V. H., \& Jago, A. G. (2007). The role of the situation in leadership. American Psychologist, 62(1), 17-24. Https://doi.org/10.1037/0003-066X.62.1.17

Zepeda, S.J. (2006). High-stakes supervisions: We must do more. International Journal of Leadership in Education, 9(1): 61-73. 